\author{
В.В. Свдокимов, д.е.н., проф. \\ О.В. Олійник, д.е.н., проф. \\ А.В. Морозов, к.т.н., доц. \\ А.О. Чагайда, к.т.н., доц. \\ Державний університет «Житомирська політехніка»
}

\title{
Історичні аспекти створення першого вищого навчального закладу індустріальної освіти Волинської губернії (до 100-річчя Житомирської політехніки)
}

Революція 1917 року та громадянська війна, що розпочалася після неї, фактично зруйнували соціально-економічні зв'язки та призвели до масової зупинки виробництв, відновлення яких було вкрай необхідне новій владі. Однією із найбільших проблем індустріально-технічної галузі стала відсутність достатньої кількості фахівців, адже значна кількість представників української інтелігенції залишила країну і не мала намірів повертатися з-за кордону. Підприємства потребували не лише інженерів, для підготовки яких не вистачало наукових та педагогічних кадрів, а й фахівців середньотехнічного рівня освіти. Для цього на виробництвах створювали освітні заклади, які не могли дати своїм слухачам достатнього рівня знань і лише готували фактично висококваліфікованих та ідеологічно мотивованих робітників. Випускники таких заводських технічних закладів мали вузьку спеціалізацію без фундаментального загальнотехнічного та освітнього рівня, але хотіли загального визнання своїх дипломів Народним комісаріатом освіти УСРР, що призвело до ретельної перевірки технікумів та закриття більшості із них у першій половині 20 -х років XX століття.

Метою дослідження $є$ аналіз передумов створення Волинського індустріального політехнікуму та початку розвитку вузькопрофільної інженерно-технічної освіти на Волині.

Влітку 1919 року у групи осіб виникла ідея відкрити у Житомирі Земельний політехнікум. Для цього було створено спеціальну комісію у складі десяти інженерів - фахівців різних спеціальностей. За кілька місяців склад комісії збільшився до 36 осіб, а результатом їі роботи став план, із відповідним проєктом положення, відкриття на Волині нового навчального закладу - Волинського земельного політехнікуму. Рішенням Волинського губернського революційного комітету від 15 березня 1920 року Губземвідділу було дозволено здійснити заходи для відкриття політехнікуму за умови комплектації контингенту слухачів виключно із селян, і лише вільні місця могли бути заповнені мешканцями міста [1]. На першу половину 1920 року на утримання політехнікуму було асигновано 1 млн карбованців і 4 квітня 1920 року у приміщенні Землемірного училища було урочисто відкрито новий заклад освіти (рис. 1), який мав три відділення - електротехнічне, меліораційно-гідротехнічне і сільськогосподарських технологій, де навчалися 245 студентів [2]. Матеріально-технічна база новоствореного навчального закладу не могла забезпечити слухачам технікуму необхідну практичну підготовку, і навчання здійснювалося лише у теоретичній частині [3]. Відсутність організаційної структури та вузькопрофільних викладачів спеціальних дисциплін негативно впливали на якість підготовки, а півтора місяця польської влади у місті взагалі змусили проводити лекції нелегально [4]. У вересні 1920 року, враховуючи бажання вступити до навчального закладу ще 130 слухачів, Рада земельного політехнікуму мала намір відкрити додатково 4 відділення: агрономічне, лісове, сільськогосподарського машинобудування і будівництва шляхів [2].

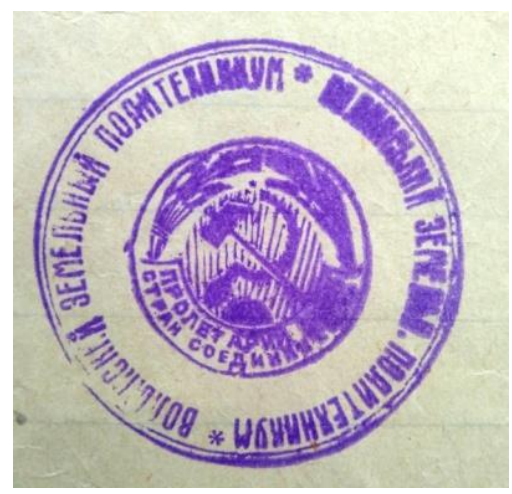

Рис. 1. Печать Волинського земельного політехнікуму [2] 
Через відсутність офіційного визнання навчального закладу фінансування діяльності політехнікуму проводилося нерегулярно, адже Народний комісаріат освіти УСРР дотримувався позиції ліквідації усіх освітніх установ, що існували за часів буржуазії. Окрім того, частину провідних викладачів взагалі викреслювали зі списків, і вони не отримували грошей за свою роботу та самостійно вирішували матеріальні проблеми. Для швидкого вирішення усіх проблем у грудні 1920 року Земельний політехнікум було вилучено із підпорядкування Губземвідділу, переведено до Губпрофосу та реорганізовано у технікум з трьома відділеннями: сільськогосподарського машинобудування, інженернобудівельним та хімічних технологій, а також річного підготовчого відділення (рис. 2).
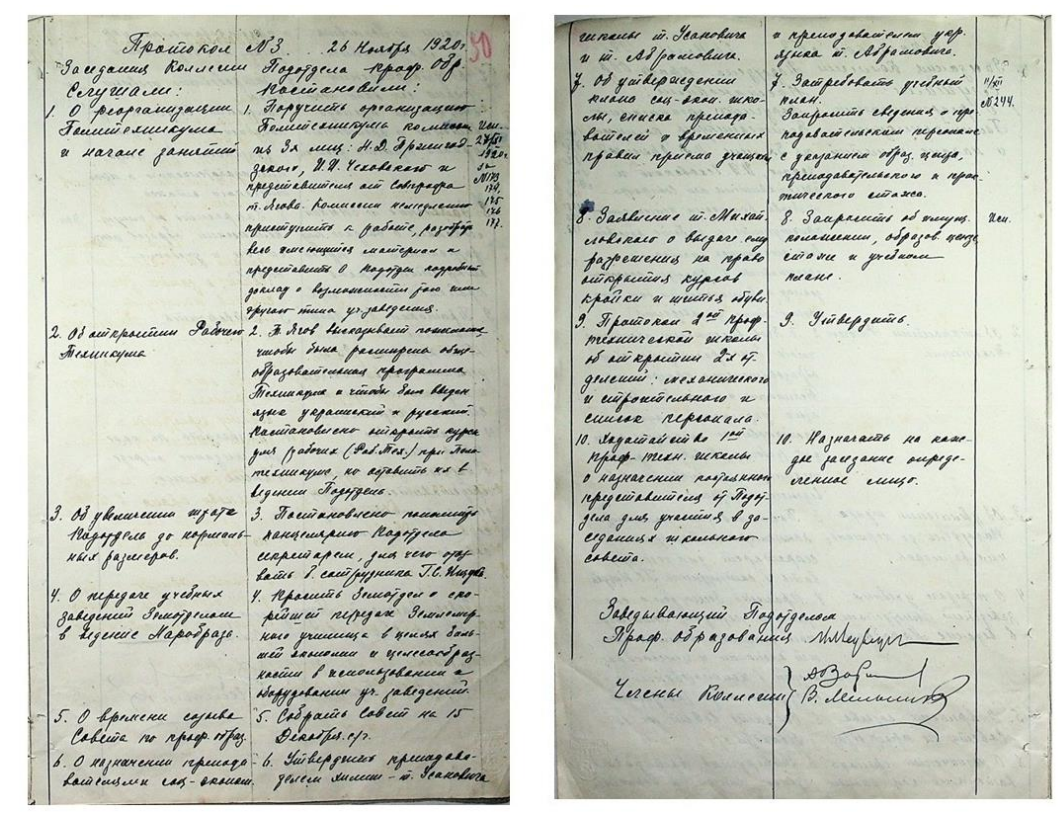

Рис. 2. Протокол засідання колегї̈ підвідділу професійної освіти від 24.11.1920 року про проведення реорганізації земельного політехнікуму [5]

Ця зміна підпорядкування дозволила стабілізувати ситуацію, i, після вирішення доволі складних питань із кошторисом і укомплектуванням викладацького складу, Волинський індустріальний технікум мав на початок 1922/1923 навчального року затверджені у Головпрофосвіті тимчасові навчальні плани для трьох факультетів: хімічного (спеціальності - технолога шкіряного, цукрового, фарфор-фаянсскляного виробництва), будівельного (спеціальності - дороги, мости 3 включенням елементів комунального будівництва) і механічного (спеціальності - сільськогосподарського машинобудування і машинознавство) $[6,7]$. Ще в другій половині XIX століття, у зв'язку зі швидким розвитком цукрового виробництва в Україні, постало питання забезпечення промисловості фахівцями середньої ланки технічного профілю. Створене у 1871 році Київське відділення Російського технічного товариства одразу поставило собі першочергове завдання створення відповідного технічного училища, що було втілено у життя в 1884 році. Цей заклад технічної освіти, що розміщувався на цукровому підприємстві графів Бобринських у місті Сміла, фактично був єдиним, до революції 1917 року, з підготовки фахівців для галузі [8]. Цукрова галузь на початку 20-х років XX століття потребувала великої кількості фахівців, і Український головний комітет професійно-технічної і спеціальнонаукової освіти при Народному комісаріаті освіти розглядав усі можливі варіанти відкриття як профільних закладів освіти, так і спеціальностей у вже існуючих $[9,10]$. Тож набір на хімічний факультет Волинського індустріального технікуму студентів за спеціальністю «Цукроваріння» було цілком обгрунтовано вимогами часу.

Зростання репутації технікуму викликало збільшення бажаючих навчатися, особливо на механічному факультеті, який закономірно став найбільшим за кількістю студентів. Зростанню абітурієнтів не завадило і запровадження оплати за навчання, яке було введено у зв'язку зі складним матеріальним становищем усіх закладів освіти. Курс навчання у Волинському індустріальному технікумі тривав 3 роки, після чого випускники мали успішно пройти ще річну практики на виробництві для отримання звання «Інженера» (рис. 3). 


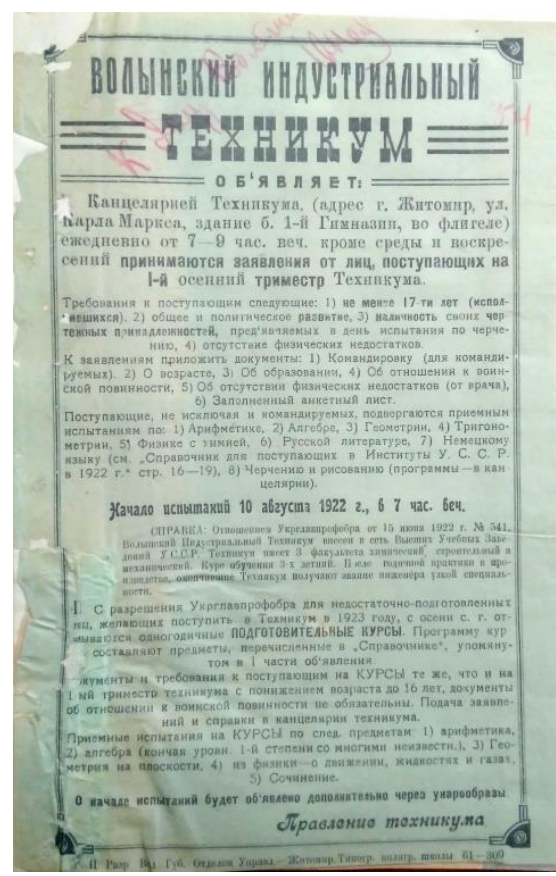

Рис. 3. Оголошення про проведення набору студентів на навчання у Волинський індустріальний технікум у 1922 рочі [11]

У 1924 році Народний комісаріат освіти УСРР ретельно переглянув наявні у його підпорядкуванні технікуми на відповідність їх діяльності освітнім вимогам. Це призвело до закриття значної частини технікумів, що змусило студентів продовжувати навчання в інших закладах освіти. Так студенти Чернігівської політехнічної школи, Чернігівського індустріально-агрономічного технікуму (рис. 4), Ніжинського хіміко-механічного технікуму (рис. 5), Мироцького технологічного технікуму постановами Головпрофосвіти були переведені до Волинського індустріального технікуму для завершення навчання і отримання свідоцтв інженерів відповідного фаху [12].

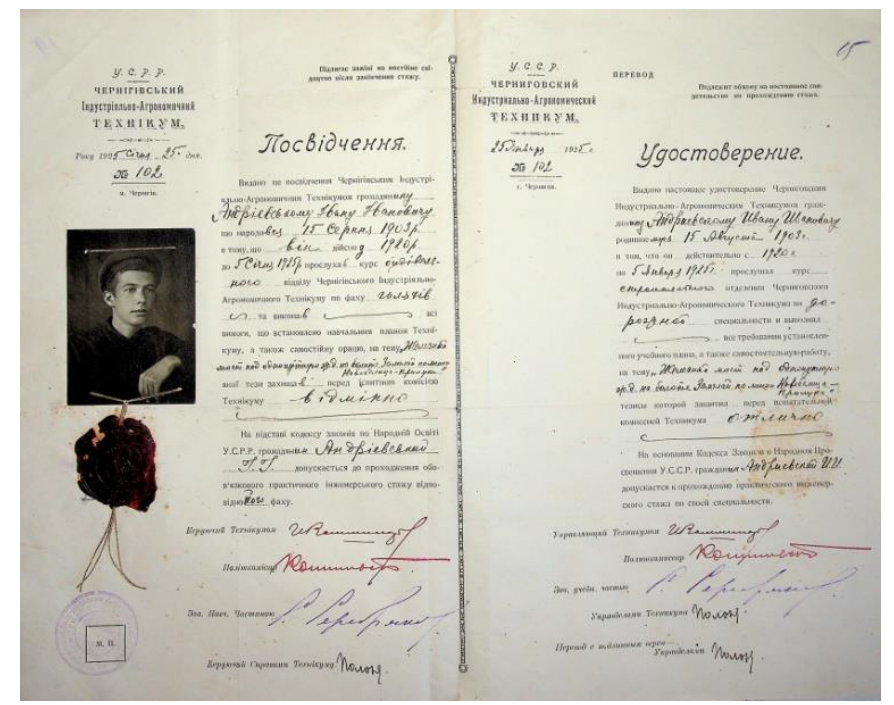

Рис. 4. Свідоцтво Чернігівського індустріальноагрономічного технікуму, видане I.I. Андрієвському, який завершував навчання у Волинському індустріальному політехнікумі [13]

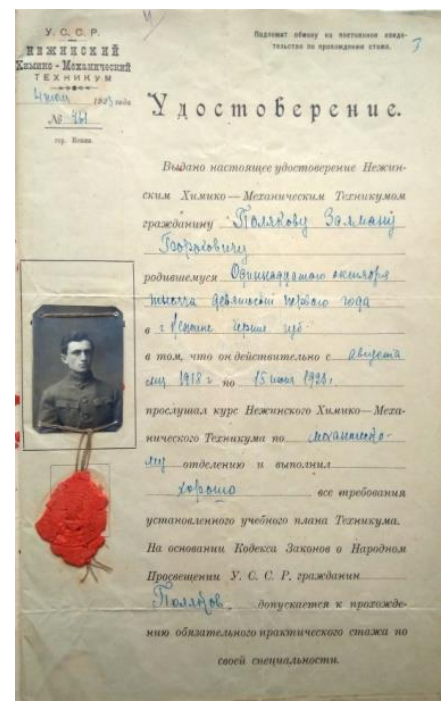

Рис. 5. Свідоцтвво Ніжинського хіміко-механічного технікуму, видане 3.Б. Полякову, який завершував навчання у Волинському індустріальному політехнікумі [14]

Під скорочення потрапили не тільки навчальні заклади, перелік спеціальностей у технікумах також було переглянуто, що продовжили освітній процес. Для цього навесні 1924 року Головінспектурою Народного комісаріату освіти УСРР було затверджено нові навчальні плани, якими підготовку студентів 
за спеціалізацією «Цукроваріння» на хімічному факультеті у Волинському індустріальному технікумі було скасовано, адже профспілка робітників цукрового виробництва разом із Цукротрестом чітко встановили мережу шкіл і вищих навчальних закладів, комплектування учнів яких відбувалося лише за рахунок робітників підприємств певного регіону, а побудова нової лабораторій у ВІТі вимагала великих капіталовкладень [15]. Таке рішення керівних органів освіти не сприйняла частина викладачів і студентів I курсу, які наполягали на отриманні саме цукрового фаху у Волинському індустріальному технікумі або жадали переведення у Смілянський цукровий технікум. Унаслідок 7 студентів II курсу отримали дозвіл на переведення, а от 45 студентів I курсу мали змінити обраний фах і продовжити навчання у Житомирі [16].

Якщо на хімічному факультеті спеціальність «Цукрове виробництво» була ліквідована, то на механічному факультеті була продовжена підготовка фахівців для цієї галузі (рис. 6). У 1926 році для стажування студентів Волинського індустріального технікуму у Подільській філії Цукротресту було виділено 28 місць [17], а для дипломних проєктів були визначені теми 3 теплосилових установок цукрових заводів із розробленням котельні, парової машини або турбіни [18]. Студенти будівельного факультету займалися проєктуванням мостів і доріг, а хімічного факультету - розробляли проєкти будівництва заводів господарчої або хімічної порцеляни та окремих цехів фаянсового заводу.

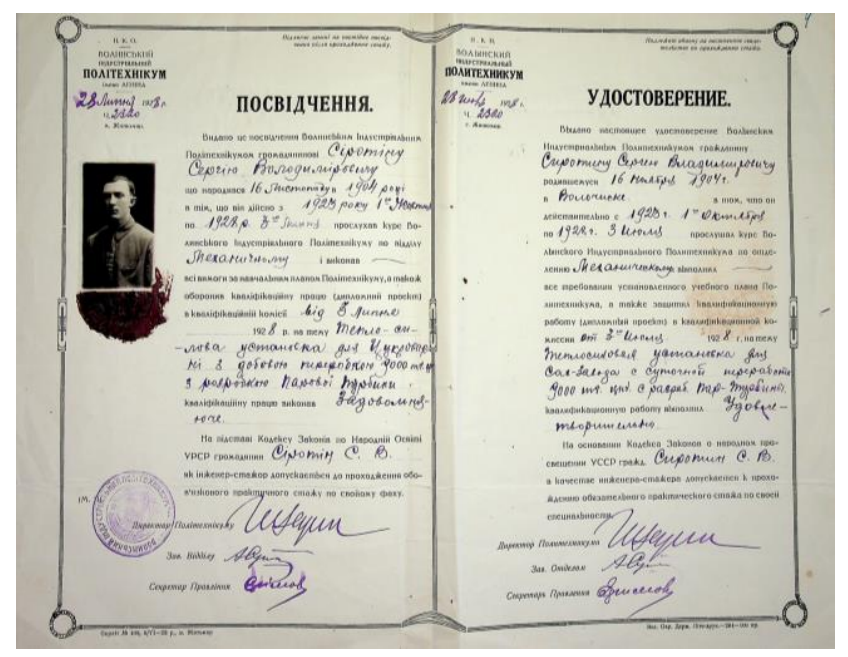

Рис. 6. Посвідчення Волинського індустріального політехнікуму, видане випускнику механічного факультету (спеціалізачія «Цукрове виробництво») Сіротіну С.В. [19]

31927 року технікум, враховуючи підготовку інженерів за великою кількістю напрямів i спеціальностей для індустріальних підприємств різних галузей промисловості, змінив назву і став називатися Волинський індустріальний політехнікум (рис. 7). Таким чином, Народний комісаріат освіти визнав не лише високий рівень підготовки випускників закладу, а і значний науковий потенціал викладачів технікуму.

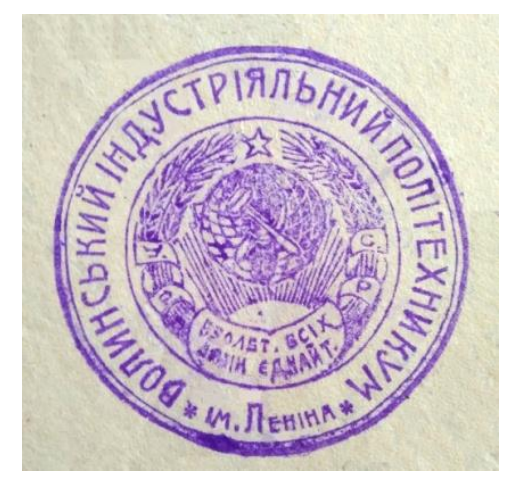

Рис. 7. Печать Волинського індустріального політехнікуму [20]

Маючи власну будівлю, технікум, окрім аудиторій, обладнав спеціалізовані хімічні лабораторії аналітичного, кількісного і якісного аналізу, геологічний музей, лабораторію для випробування будівельних матеріалів, лабораторії керамічного виробництва, які використовували також для навчання 
учні хімічної профшколи. Це дало значний поштовх для підвищення рівня потенційних абітурієнтів, які після закінчення профшколи продовжували навчання в політехнікумі.

Висновки. Значні проблеми, що виникли у підприємств із пошуком фахівців індустріальнотехнічного напряму, зумовили відкриття відповідних закладів освіти, що займалися вузькопрофільною підготовкою інженерів. На початку 20-х років XX століття у Волинській губернії було створено, у той час, єдиний заклад освіти, що мав готувати таких спеціалістів, - Волинський індустріальний технікум (згодом - політехнікум), студенти якого отримували знання під час навчання на трьох факультетах: механічному, будівельному і хімічному. Під час становлення технікум мав значну підтримку керівників міста і губернського відділу професійної освіти, що дозволило у короткий термін провести ремонти приміщень і створити необхідну для навчання матеріально-технічну базу.

\section{Список використаної літератури:}

1. Выписка из протокола заседания Волынского Губернского Революционного Комитета от 15 марта 1920 г. // Державний архів Житомирської області. - Ф. 125, оп. 3, спр. 58, арк. 70.

2. Т. Председателю Волгубревкома // Державний архів Житомирської області. - Ф. 2686, оп. 1, спр. 6, арк. 75-76.

3. Отчет о состоянии Волынского индустриального техникума на 1 января 1922 г. // ЦДАВО України. Ф. 166, оп. 2, спр. 1330, арк. 40.

4. Докладная записка слушателей Волынского техникума Наркомпросу т. Гринько // ЦДАВО України. Ф. 166, оп. 1, спр. 1023, арк. 15-18.

5. Протокол № 3 заседания коллегии подотдела проф. образования от 26 ноября 1920 г. // Державний архів Житомирської області. - Ф. 31, оп. 1, спр. 10, арк. 50.

6. Свдокимов В.В. Житомирська політехніка: 100 років від початку технічної освітньої діяльності / B.В. Свдокимов, О.В. Олійник, А.В. Морозов, А.О. Чагайда // Економіка, управління та адміністрування. Житомир, 2020. - № 1 (91). - С. 3-8.

7. Вр. Учебный план // ЦДАВО України. - Ф. 166, оп. 2, спр. 1330, арк. 30-32.

8. Отчет о состоянии Смелянских технических классов К.О.И.Р.Т.О., учрежденных в 1884 году в память графа Алексея Алексеевича Бобринского, за 1914-15 гг. // Записки Киевского отделения императорского русского технического общества по свеклосахарной промышленности. - 1916. - T. XLVI, № 5. - С. 25-28.

9. О техникуме сахарного производства : протокол № 123 от 9 сентября 1921 г. // Бюллетень Укрглавпрофобра. - 1921. - № 6-7. - 11 с.

10. К вопросу о профессионально-техническом образовании в сахарной промышленности // Вісник цукрової промисловості. - 1920. - Ч. 7-10. - С. 191-192.

11. Волынский индустриальный техникум // ЦДАВО України. - Ф. 166, оп. 2, спр. 1329, арк. 54.

12. Євдокимов B.B. Становлення вищої технічної школи в Україні у 20-ті роки XX сторіччя / В.В. Свдокимов, О.В. Олійник, А.О. Чагайда // Економіка, управління та адміністрування. - Житомир, 2019. - № 3 (89). C. 3-7.

13. Справа стажера Андрієвського І.І. // Державний архів Житомирської області. - Ф. 457, оп. 1, спр. 336, арк. 15.

14. Справа стажера Полякова З.Б. // Державний архів Житомирської області. - Ф. 457, оп. 1, спр. 223, арк. 3.

15. Волынскому индустриальному техникуму. 18.04.1924 г. // ЦДАВО України. - Ф.166, оп. 3, спр. 589, арк. 19.

16. Свдокимов В.В. Становлення Волинського (Житомирського) індустріального технікуму як єдиного вищого технічного навчального закладу Волинської губернії / В.В. Євдокимов, О.В. Олійник, А.О. Чагайда // Технічна інженерія. - Житомир, 2019. - № 2 (84). - С. 3-9.

17. Лист до Волинського індустріального технікуму // ЦДАВО України. - Ф. 166, оп. 6 II, спр. 3717, арк. 13.

18. Примерные темы дипломных заданий для студентов мехфака ВИТа // ЦДАВО України. - Ф. 166, оп. 6 II, спр. 3717 , арк. 43.

19. Діло студента Сіротіна Сергія Володимировича // Державний архів Житомирської області. - Ф. 457, оп. 1, спр. 228, арк. 4.

20. Справа про кваліфікацію стажера Бурчак-Абрашовича М.В. // Державний архів Житомирської області. Ф. 457, оп. 1, спр. 146.

\section{References:}

1. Derzhavnyj arhiv Zhytomyrs'koi' oblasti (1920), Vypiska iz protokola zasedaniya Volynskogo Gubernskogo Revolyutsionnogo Komiteta ot 15 marta 1920 g., F. 125, op. 3, spr. 58, ark. 70.

2. Derzhavnyj arhiv Zhytomyrs'koi' oblasti, T. Predsedatelyu Volgubrevkoma, F. 2686, op. 1, spr. 6, ark. 75-76.

3. CDAVO Ukrai'ny, Otchet o sostojanii Volynskogo industrial'nogo tehnikuma na 1 janvarja 1922 g., F. 166, op. 2, spr. 1330, ark. 40.

4. CDAVO Ukrai'ny, Dokladnaja zapiska slushatelej Volynskogo tehnikuma Narkomprosu t. Grin'ko, F. 166, op. 1, spr. 1023, ark. 15-18.

5. Derzhavnyj arhiv Zhytomyrs'koi' oblasti, Protokol No. 3 zasedanija kollegii podotdela prof. Obrazovanija, F. 31, op. 1, spr. 10, ark. 50 .

6. Jevdokymov, V.V., Olijnyk, O.V., Morozov, A.V. and Chagajda, A.O. (2020), «Zhytomyrs'ka politehnika: 100 rokiv vid pochatku tehnichnoi' osvitn'oi' dijal'nosti», Ekonomika, upravlinnja ta administruvannja, Zhytomyr, No. 1 (91), pp. 3-8.

7. CDAVO Ukrai'ny, Vr. Uchebnyj plan, F. 166, op. 2, spr. 1330, ark. 30-32. 
8. «Otchet o sostojanii Smeljanskih tehnicheskih klassov K.O.I.R.T.O., uchrezhdennyh v 1884 godu v pamjat' grafa Alekseja Alekseevicha Bobrinskogo, za 1914-15 gg.»(1916), Zapiski Kievskogo otdelenija imperatorskogo russkogo tehnicheskogo obshhestva po sveklosaharnoj promyshlennosti, T. XLVI, No. 5, pp. 25-28.

9. Ukrglavprofobr (1921), «O tehnikume saharnogo proizvodstva», protokol No. 123 ot 9 sentjabrja 1921 g., Bjulleten' Ukrglavprofobra, No. 6-7, 11 p.

10. «K voprosu o professional'no-tehnicheskom obrazovanii v saharnoj promyshlennosti» (1920), Visnyk cukrovoi' promyslovosti, Part 7-10, pp. 191-192.

11. CDAVO Ukrai'ny, Volynskij industrial'nyj tehnikum, F. 166, op. 2, spr. 1329, ark. 54.

12. Jevdokymov, V.V., Olijnyk, O.V. and Chagajda, A.O. (2019), «Stanovlennja vyshhoi' tehnichnoi' shkoly v Ukrai'ni u 20-ti roky XX storichchja», Ekonomika, upravlinnja ta administruvannja, Zhytomyr, No. 3 (89), pp. 3-7.

13. Derzhavnyj arhiv Zhytomyrs'koi' oblasti, Sprava stazhera Andrijevs'kogo I.I., F. 457, op. 1, spr. 336, ark. 15.

14. Derzhavnyj arhiv Zhytomyrs'koi' oblasti, Sprava stazhera Poljakova Z.B., F. 457, op. 1, spr. 223, ark. 3.

15. CDAVO Ukrai'ny, Volynskomu industrial'nomu tekhnikumu. 18.04.1924 g., F.166, op. 3, spr. 589, ark. 19.

16. Jevdokymov, V.V., Olijnyk, O.V. and Chagajda, A.O. (2019), «Stanovlennja Volyns'kogo (Zhytomyrs'kogo) industrial'nogo tehnikumu jak jedynogo vyshhogo tehnichnogo navchal'nogo zakladu Volyns'koi' gubernii'», Tehnichna inzhenerija, Zhytomyr, No. 2 (84), pp. 3-9.

17. CDAVO Ukrai'ny, Lyst do Volyns'kogo industrial'nogo tehnikumu, F. 166, op. 6 II, spr. 3717, ark. 13.

18. CDAVO Ukrai'ny, Primernye temy diplomnykh zadanii dlya studentov mekhfaka VITa, F. 166, op. 6 II, spr. 3717 , ark. 43.

19. Derzhavnyj arhiv Zhytomyrs'koi' oblasti, Dilo studenta Sirotina Sergija Volodymyrovycha, F. 457, op. 1, spr. 228, ark. 4.

20. Derzhavnyj arhiv Zhytomyrs'koi' oblasti, Sprava pro kvalifikaciju stazhera Burchak-Abrashovycha M.V., F. 457, op. 1 , spr. 146.

Свдокимов Віктор Валерійович - доктор економічних наук, професор, ректор Державного університету «Житомирська політехніка».

Наукові інтереси:

- проблеми національної економічної безпеки;

- розвиток вищої освіти в Україні.

Олійник Оксана Вікторівна - доктор економічних наук, професор, перший проректор Державного університету «Житомирська політехніка».

Наукові інтереси:

- обліково-аналітичне забезпечення системи управління;

- розвиток вищої освіти в Україні.

Морозов Андрій Васильович - кандидат технічних наук, доцент, доцент Державного університету «Житомирська політехніка».

Наукові інтереси:

- розвиток вищої освіти в Україні.

Чагайда Андрій Олегович - кандидат технічних наук, доцент кафедри туризму та готельноресторанної справи Державного університету «Житомирська політехніка».

Наукові інтереси:

- $\quad$ проблеми теорії та практики технології виробництва на підприємствах харчової промисловості;

- мінітехнології на підприємствах готельно-ресторанного господарства;

- розвиток вищої освіти в Україні. 